\title{
PENGARUH KUALITAS PELAYANAN TERHADAP KEPUASAN DAN LOYALITAS MAHASISWA PADA INSTITUTE OF BUSINESS (IOB) DI TIMOR-LESTE
}

\author{
NATALINO ALARICO BARRETO XIMENES \\ Fakultas Ekonomi dan Bisnis Universitas Udayana (Unud), Bali, Indonesia \\ Email: natabarretoximenes@gmail.com
}

\begin{abstract}
ABSTRAK
Penelitian ini bertujuan untuk mengetahui pengaruh kualitas pelayanan terhadap kepuasan dan loyalitas mahasiswa IOB di Timor-Leste. Karena untuk dapat tetap bersaing dalam pelayanan jasa pendidikan di Timor-Leste, IOB harus terus peka dan memperhatikan kualitas pelayanan yang IOB berikan kepada para mahasiswanya, guna tercapai kepuasan serta loyalitas dari para mahasiswa IOB. Dengan demikian, IOB dapat memenangkan persaingan di pasar pelayanan jasa pendidikan.

Responden penelitian adalah mahasiswa IOB yang sedang aktif kuliah, dengan jumlah responden penelitian ditetapkan sebanyak 104, mengunakan teknik pengambilan sampel yaitu purposive sampling. Peneliitian ini menggunakan analisis Structural Equation Modeling (SEM) dengan bantuan program AMOS. Hasil penelitian ini menunjukkan bahwa hipotesis yang diajukan seluruhnya dapat diterima yaitu 1) kualitas pelayanan berpengaruh positif dan signifikan terhadap kepuasan mahasiswa, 2) kualitas pelayanan berpengaruh positif dan signifikan terhadap loyalitas mahasiswa, 3) kepuasan mahasiswa berpengaruh positif dan signifikan terhadap loyalitas mahasiswa. Berdasarkan hasil responden pada penelitian ini, masih terdapat mahasiswa IOB yang belum sepenuhnya puas dengan kualitas pelayanan yang diterapkan oleh manajemen IOB. Implikasi manajerial dari penelitian ini yaitu manajemen IOB seharusnya melakukan evaluasi rutin, dan melakukan perbaikan kinerja kualitas pelayanan yang telah diterapkan, untuk meminimalkan keluhan, sehingga meningkatkan kepuasan serta loyalitas mahasiswa.
\end{abstract}

Kata kunci : kualitas pelayanan, kepuasan mahasiswa, loyalitas mahasiswa.

\begin{abstract}
The aim of this study is to understand the influence of the service quality for the student satisfaction and loyalty. To keep compete on the path, IOB should maintain the good service quality to its students, in order to gain the loyalty from its students. Therefore, with the good quality services, IOB could stand on the competition.

Respondent of this study are the active IOB students, with age minimum 17 years old and maximum 35 years old. The total respondent for this study is 104 respondents, using the purposive sampling technique, and Structural Equation Modeling (SEM) as the data analysis tool. The result of this study showed that the hypothesis put forward entirely acceptable: 1) service quality has positive and significant impact on student satisfaction, 2) service quality has positive and significant impact on student loyalty, 3) student satisfaction has positive and significant impact on student loyalty. Managerial implication from this study is the management of IOB should have regular evaluation for its service quality, and also perform correction and improvement to reduce students complains, in order to increase the student satisfaction and loyalty.
\end{abstract}

Key Words : Service quality, student satisfaction, student loyalty, IOB. 


\section{PENDAHULUAN}

\section{Latar Belakang}

Lingkungan pada sektor pendidikan didunia saat ini memiliki peran yang sanggat penting demi mendukung pembangunan suatu negara. Sektor pendidikan menjadi sektor yang menentukan kemajuan suatu negara pada masa sekarang dan pada masa yang akan datang.Khususnya pada era globalisasi saat ini, merupakan tantangan tersendiri bagi Perguruan Tinggi dalam menyiapkan lulusannya agar mampu berkompetisi dalam memperebutkan pasar kerja dan menghasilkan lulusan yang inovatif dan kreatif.

Kualitas pelayanan menjadi peran yang sangat penting demi kelanjutan suatu intitusi pendidikan. Jikalau intitusi pendidikan tersebut memiliki kualitas pelayanan yang baik, akan dengan sendirinya tercapai kepuasan dan loyalitas oleh para mahasiswa.Kesetiaan pelanggan merupakan suatu kondisi dimana pelanggan melakukan pembelian ulang dimasa yang akan datang. Demi mencapai kepuasan para mahasiswanya, IOB perlu memperhatikan masukan, kritik, dan saran yang diberikan oleh para mahasiswanya, sehingga terus memperbaiki diri demi tercapainya kepuasan dan loyalitas mahasiswa.Selain masukan, kritik dan saran yang diberikan oleh para mahasiswa, IOB pun perlu memperhatikan faktor eksternal yaitu para pesaing yang juga terus berkembang dan bersaing disekitarnya. Dengan adanya pesaing lainnya, menjadi dorongan bagi IOB untuk terus memperbaiki diri sehingga dapat mecapai tujuan utama yaitu kepuasan mahasiswa dan dengan sendirinya akan tercipta loyalitas mahasiswa terhadap IOB. Beradasarkan latar belakang masalah maka tujuan penelitian ini adalah 
untuk menjelaskan pengaruh kualitas pelayanan yang terdiri atas tangible, reliability, responsiveness, assurance, dan empathy terhadap kepuasan mahasiswa IOB di Timor-Leste, untuk menjelaskan pengaruh kualitas pelayanan yang terdiri atas tangible, reliability, responsiveness, assurance, dan empathy terhadap loyalitas mahasiswa IOB di Timor-Leste dan untuk menjelaskan pengaruh kepuasan mahasiswa terhadap loyalitas mahasiswa IOB di Timor-Leste.

\section{KAJIAN PUSTAKA}

\section{Kualitas Pelayanan}

Kualitas pelayanan didefinisikan sebagai penilaian pelanggan atas keunggulan atau keistimewaan suatu produk atau layanan secara menyeluruh (Zeithaml, 1988). Parasuraman et al., (1988) mendefinisikan kualitas pelayanan sebagai suatu bentuk sikap, berkaitan tetapi tidak sama dengan kepuasan, sebagai hasil dari perbandingan antara harapan dengan kinerja. Storey dan Wood (1998) berpendapat bahwa manajemen harus memahami keseluruhan layanan yang ditawarkan dari sudut pandang pelanggan. Barata (2006) menyatakan bahwa ukuran kualitas pelayanan bukan hanya ditentukan oleh pihak yang melayani saja tetapi lebih banyak ditentukan oleh pihak yang dilayani, karena merekalah yang menikmati layanan sehingga dapat mengukur kualitas pelayanan berdasarkan harapan-harapan mereka dalam memenuhi kepuasannya.

Dalam salah satu studi mengenai kualitas pelayanan oleh Parasuraman (1988) dalam Lupiyoadi (2009) yang melibatkan 800 pelanggan (yang terbagi 
dalam empat perusahaan) berusia 25 tahun ke atas menytakan bahwa terdapat lima dimensi kualitas pelayanan sebagai berikut:

Berwujud (Tangible), yaitu kemampuan suatu perusahaan dalam menunjukkan eksistensinya kepada pihak eksternal. Penampilan dan kemampuan sarana dan prasarana fisik perusahaan yang dapat diandalkan dan keadaan lingkungan sekitarnya merupakan bukti nyata dari pelayanan yang diberikan oleh pemberi jasa. Hal ini meliputi fasilitas fisik (gedung, gudang, dan lain-lain), perlengkapan dan peralatan yang dipergunakan (teknologi), serta penampilan pegawainya.

Keandalan (Reliability), yaitu kemampuan perusahaan untuk memberikan pelayanan sesuai yang dijanjikan secara akurat dan terpercaya. Kinerja harus sesuai dengan harapan pelanggan yang berarti ketepatan waktu, pelayanan yang sama untuk semua pelanggan tanpa kesalahan, sikap yang simpatik, dan dengan akurasi yang tinggi.

Ketanggapan (Responsiveness), yaitu suatu kebijakan untuk membantu dan memberikan pelayanan yang cepat (responsif) dan tepat kepada pelanggan, dengan penyampaian informasi yang jelas. Membiarkan konsumen menunggu menyebabkan persepsi yang negatif dalam kualitas pelayanan.

Jaminan (Assurance), yaitu pengetahuan, kesopansantunan, dan kemampuan para pegawai perusahaan untuk menumbuhkan rasa percaya para pelanggan kepada perusahaan. Hal ini meliputi beberapa komponen antara lain komunikasi (communication), kredibilitas (credibility), keamanan (security), kompetensi (competence), dan sopan santun (courtesy). 
Empati (Emphaty), yaitu memberikan perhatian yang tulus dan bersifat individual atau pribadi yang diberikan kepada para pelanggan dengan berupaya memahami keinginan konsumen. Di mana suatu perusahaan diharapkan memiliki pengertian dan pengetahuan tentang pelanggan, memahami kebutuhan pelanggan secara spesifik, serta memiliki waktu pengoperasian yang nyaman bagi pelanggan.

\section{Kepuasan Pelanggan}

Kepuasan merupakan tingkat perasaan di mana seseorang menyatakan hasil perbandingan atas kinerja produk (jasa) yang diterima dan yang diharapkan (Kotler,1997 dalam Lupiyoadi, 2009). Sedangkan menurut Fonell dalam Tjiptono (2007), kepuasan pelanggan adalah evaluasi purnabeli keseluruhan. Tse dan Wilton dalam Tjiptono (2007) menjelaskan kepuasan pelangan sebagai respon konsumen pada evaluasi persepsi terhadap perbedaan antara ekspektasi awal (atau standar kinerja tertentu) dan kinerja aktual produk sebagaimana dipersepsikan setelah konsumsi produk.

Menurut Wilkie dalam Tjiptono (2000), kepuasan pelanggan merupakan suatu tanggapan emosional pada evaluasi terhadap pengalaman komsumsi atas suatu produk atau jasa. Sementara itu Cadotte et al.,dalamTjiptono (2007) menjelaskan kepuasan pelanggan sebagai perasaan yang timbul setelah mengevaluasi pengalaman pemakaian produk. Menurut Peter (2000), jika konsumen merasa puas dengan suatu produk atau merek, mereka cenderung akan terus membeli dan menggunakannya serta memberitahu orang lain tentang pengalaman mereka yang menyenangkan dengan produk atau merek tersebut. Jika mereka tidak dipuaskan, mereka cenderung akan beralih produk atau merek serta 
mengajukan keberatan pada produsen, pengecer, dan bahkan menceritakannya kepada konsumen lainnya.

Supranto (2001) menyatakan, pelanggan memang harus dipuaskan, sebab kalau tidak puas akan meninggalkan perusahaan dan menjadi pelanggan pesaing, hal ini akan menyebabkan penurunan penjualan dan pada gilirannya akan menurunkan laba dan bahkan kerugian. Menurut Engel et al. (1995) kepuasan pelanggan diwujudkan dalam bentuk kognitif dan afektif indikator yang digunakan untuk mengukur variable kepuasan pelanggan, meliputi:

Atribut pelayanan adalah penyampaian pelayanan yang tepat waktu, akurat dengan perhatian dan keramahan.

Garansi pelayanan adalah ganti rugi yang diberikan sektor pelayanan untuk mengurangi resiko atau kerugian di pihak pelanggan sebelum dan sesudah pembelian atau pemanfaatan pelayanan.

Penanganan keluhan adalah tindakan dalam mengantisipasi agar tidak terjadi kekecewaan pelanggan atau tindakan penyelesaian masalah (keluhan).

Kemudahan dihubungi, sektor pelayanan publik selalu membuka kesempatan kapanpun, menemui siapapun untuk menampung komentar, saran, kritik, pertanyaan maupun keluhan dari pelanggan.

\section{Loyalitas Konsumen}

Loyalitas konsumen dapat didefinisikan sebagai suatu perilaku pembelian pengulangan yang telah menjadi kebiasaan, yang mana telah ada keterkaitan dan keterlibatan tinggi pada pilihan konsumen terhadap obyek tertentu, dan bercirikan 
dengan ketiadaan pencarian informasi eksternal dan evaluasi alternatif (Engel et al., 1995).

Keputusan pelanggan untuk bersikap loyal atau tidak bersikap loyal merupakan akumulasi dari banyak masalah kecil dalam perusahaan (Kotler, 2009). Loyalitas secara harfiah diartikan kesetiaan, yaitu kesetiaan seseorang terhadap suatu objek. Mowen dan Minor (1998) dalamLupiyoadi (2009) mendefinisikan loyalitas sebagai kondisi di mana pelanggan mempunyai sikap positif terhadap suatu merek, mempunyai komitmen terhadap merek tersebut, dan bermaksud meneruskan pembeliannya di masa medatang. Ini berarti loyalitas selalu berkaitan dengan preferensi pelanggan dan pembelian aktual.

Loyalitas konsumen merupakan manifestasi dan kelanjutan dari kepuasan konsumen dalam menggunakan fasilitas maupun jasa pelayanan yang diberikan oleh pihak institusi, serta untuk tetap menjadi konsumen dari institusi tersebut. Loyalitas adalah bukti konsumen yang selalu menjadi pelanggan, yang memiliki kekuatan dan sikap positif atas institusi itu. Menurut Porter dalamDavid (2009) menyatakan kunci keunggulan bersaing dalam situasi yang penuh persaingan adalah kemampuan perusahaan dalam meningkatkan kesetiaan pelanggan. Kesetiaan pelanggan akan menjadi kunci sukses, tidak hanya dalam jangka pendek tetapi keunggulan bersaing yang berkelanjutan. Hal ini karena kesetiaan pelanggan memiliki nilai strategik bagi perusahaan.

\section{Kerangka Konseptual}

Perusahaan dalam menciptakan kepuasan pelangan, harus dapat meningkatkan kualitas pelayanannya. Kepuasan pelanggan dapat diciptakan melalui kualitas 
pelayanan yang diberikan oleh perusahaan kepada para pelangganya. Semakin baik kualitas pelayanannya, akan semakin tinggi pula kepuasan pelangan terhadap perusahaan tersebut. Dengan sendirinya, jika pelangan terpuaskan oleh produk/jasa tersebut, maka dengan sendirinya pelangan tersebut akan loyal terhadap produk/jasa perusahaan tersebut. Tingginya kualitas pelayanan juga tidak lepas dari dukungan internal perusahaan, terutama dukungan dari tenaga sumber daya manusianya (Chen, 2007).

Kualitas pelayanan merupakan salah satu kunci bagi keberhasilan perusahaan. Tidak ada cara lain bagi perusahaan untuk tetap eksis dan terus berkembang di industri yang digelutinya, selain harus memberikan kualitas pelayan yang terbaik kepada para pelangannya. Cara tersebut perlu dicermati dan diperlukan perhatian khusus dan pihak manajemen perusahaan, agar bisa tetap bersaing dalam dunia persaingan yang sangat ketat pada saat ini. Sehingga pelaku usaha perlu melakukan usaha pemasaran yang baik. Pemasaran itu sendiri adalah proses merencanakan konsepsi, harga , promosi, dan distribusi ide, menetapkan peluang yang dapat memuaskan individu dan sesuai degan tujuan organisasi (Kotler, 2002).

Sesuai dengan tujuan penelitian, jumlah variable yang teridentifikasi, maka dapat dibangun suatu konsep model hubungan antara kualitas pelayanan dengan kepuasan dan loyalitas mahasiswa. Kualitas pelayanan yang diberikan oleh IOB kepada mahasiswa, sangatlah berpengaruh terhadap kepuasan dan loyalitas mahasiswa itu sendiri. 
Berdasarkan uraian karangka berpikir tersebut, maka dapat digambarkan hubungan antara kualitas pelayanan yang dapat meningkatkan kepuasan dan loyalitas mahasiswa adalah sebagai berikut

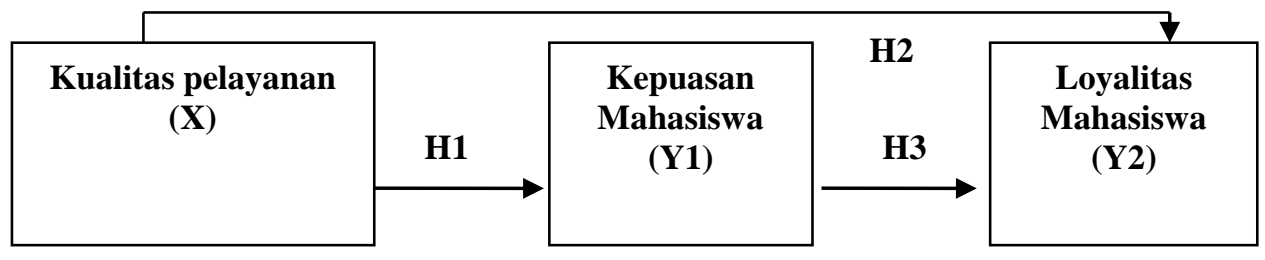

Gambar 1 Kerangka Konseptual Penelitian

\section{Hipotesis Penelitian}

Berdasarkan kerangkah pemikiran dan modal konseptual yang telah dipaparkan maka dirumuskan hipotesis penelitian sebagai berikut :

1.Pengaruh kualitas pelayanan terhadap kepuasan mahasiswa

Kualitas pelayanan yang dirasakan olen pelangan akan menentukan persepsi pelangan terhadap kinerja yang pada gilirannya akan berdampak pada kepuasan pelangan (Chandra, 2002). Menurut Lee et al. (2000) dalam Purnomo (2007) bahwa kepuasan konsumen terbentuk dari kualitas pelayanan, dimana kualitas pelayanan sebagai bahan evaluasi secara keseluruhan untuk menilai kepuasan konsumen setelah melakukan transaksi. penelitian ini dilakukan pengukuran kualitas pelayanan berdasarkan pada lima konsep kualitas pelayanan oleh Parasuraman et al.,(1988) dalam Tjiptono et al., (2011), yaitu reliability, responsiveness, assurance, empathy dan tangible.Berdasarkan hasil penelitian tersebut maka diajukan hipotesis penelitian : 
H1 : Kualitas pelayanan berpengaruh positif dan signifikan terhadap kepuasan mahasiswa.

2. Pengaruh kualitas pelayanan terhadap loyalitas mahasiswa

Parasuraman et al. (1998) menemukan hubungan positif dan signifikan antara persepsi kualitas pelayanan dengan keinginan untuk merekomendasikan kepada orang lain. Unsur loyalitas lain yang diwujudkan dalam komunikasi pengalaman positif seseorang. Setiap penyedia jasa wajib menyampaikan jasa yang berkualitas terbaik kepada para pelanggan sasaranya (Tjiptono 2011). Menurut penelitian yang dilakukan oleh Kresnamurti, dkk,(2011),menyatakan bahwa kualitas pelayanan berpengaruh positif dan signifikan terhadap loyalitas pelangan. Senada dengan penelitian yang dilakukan oleh Rinala, dkk (2013), menyatakan bahwa adanya pengaruh yang positif dan signifikan antara kualitas pelayanan terhadap loyalitas mahasiswa. Berdasarkan hasil penelitian tersebut maka hipotesis yang diajukan :

H2 : Kualitas pelayanan berpengaruh positif dan signifikan terhadap loyalitas mahasiswa.

3. Pengaruh kepuasan mahasiswa terhadap loyalitas mahasiswa Fornell (1992) dalam Kandampully (2000) telah meneliti hubungan antara kepuasan pelanggan dan kesetiaan pelanggan dimana perilaku pelanggan yang merasa puas akan menjadi lebih setia.Berdasarkan penelitian yang dilakukan oleh Olsen (2003) yang telah membuktikan bahwa kepuasan pelanggan secara signifikan mempengaruhi kesetiaan pelanggan. Senada dengan penelitian yang dilakukan oleh Rinala, dkk, (2013), menyatakan bahwa adanya pengaruh yang 
positif dan signifikan antara kepuasan mahasiswa terhadap loyalitas mahasiswaBerdasarkan atas hasil penelitian tersebut maka hipotesis yang dapat diajukan:

H3 :Kepuasan mahasiswa berpengaruh positif dan signifikan terhadap loyalitas mahasiswa.

\section{METODE PENELITIAN}

\section{Rancangan dan Ruang Lingkup Penelitian}

Penelitian ini merupakan penelitian survey, karena dalam pengumpulan data dilakukan melalui kuisioner yang diberikan pada responden yaitu mahasiswa, yang digunakan sebagai alat pengumpul data primer. Menurut pendapat Aritonang (2007) desain penelitian dibedakan menjadi penelitian eksploratif dan konklusif. Penelitian konklusif dibedakan lagi menjadi penelitian deskritif dan eksperimen. Penelitian deskritif dibedakan menjadi penelitian cross-sectional dan longitudional. Variabel pada penelitian cross-sectional disebut juga sebagai survey sampel bila hanya sebagian subjek populasi yang diteliti.

Lokasi dan subjek penelitian

Penelitian ini membahas tentang perilaku mahasiswa IOB yang sedang aktif berkuliah di IOB, secara lebih spesifik yang diteliti adalah kualitas pelayanan yang diberikan oleh IOB kepada mahasiswa, kepuasan yang dirasakan oleh mahasiswa sendiri, dan bagaimana loyalitas dari para mahasiswa IOB itu sendiri. Penelitian ini dilakukan di kampus IOB yang terletak di kota Dili, yang beralamat di Jalan Praia dos Coqueiros dan Jalan Fomento II. Kuesioner penelitian yang 
disebarkan, diberikan kepada mahasiswa di kampus IOB, baik itu kelas regular maupun kelas extension.

Berdasarkan rumusan masalah, kajian pustaka dan hipotesis yang digunakan, variabel penelitian ini dibedakan antara variabel eksogenus (variabel bebas), dan variabel endogenus (variable tidak bebas).Variabel eksogenus merupakan variabel bebas atau variabel independen yang pada penelitian ini adalah Kualitas Pelayanan (X). Variabel endogenus merupakan variabel tidak bebas, dapat berupa variabel dependent atau variabel antara. Dalam penelitian ini, variabel endogenus adalah Kepuasan Mahasiswa $\left(\mathrm{Y}_{1}\right)$ dan Loyalitas Mahasiswa $\left(\mathrm{Y}_{2}\right)$.

\section{Definisi Operasional Variabel Penelitian}

Kualitas Pelayanan adalah tingkatan kualitas pelayanan yang diberikan oleh manajemen IOB kepada mahasiswa IOB itu sendiri. Kualitas pelayanan ini terdiri atas lima dimensi (Parasuraman ; 1998 ) sebagai berikut :

(1) Keandalan (Reliability) adalah kemampuan staff IOBuntuk melaksanakan layanan yang dijanjikan secara meyakinkan dan akurat

(2) Daya Tanggap (reposiveness) adalah kesediaan staff IOB untuk membantu mahasiswa dan memberikan layanan dengan cepat

(3). Jaminan (Assurance) adalah pengetahuan dan kesopanan staff IOB yang dapat menimbulkan kepercayaan dan keyakinan dari mahasiswa IOB.

(4). Empati (Empathy) adalah kesediaan staff IOB untuk memberikan perhatian yang mendalam dan khusus kepada masing-masing mahasiswa. 
(5) Bukti Fisik (Tangibles) adalah pemampilan fasilitas fisik seperti fisik, kelengkapan fasilitas,kebersihan ruangan, dan penampilan staff IOB yang dapat dilihat langsung oleh mahasiswa.

Kepuasan Mahasiswa merupakan tingkat perasaan senang atau rasa kecewa mahasiswa setelah memilih IOB sebagai penyedia jasa pendidikan tinggi dan memulai studi di IOB.

Loyalitas Mahasiswa merupakan kesediaan mahasiswa untuk merekomendasikan kepada keluarga, teman dan kenalan setelah merasakan pelayanan yang diberikan oleh manajemen IOB.

\section{METODE PENELITIAN}

\section{Prosedur Pengumpulan Data}

\section{Jenis Data}

Data yang digunakan dalam penelitian ini adalah data primer dan data sekunder. Penjelasan mengenai masing-masing jenis data tersebut dijelaskan lebih rinci sebgaai berikut :

a) Data primer merupakan data yang diperoleh langsung dari mahasiswa melalui penyebaran kuesioner.

b) Data sekunder merupakan data yang diperoleh melalui dokumentasi dan reverensi yang berkaitan dengan penelitian ini yaitu informasi dan data dari manajemen IOB, literature dan jurnal penelitian terlebih dahulu yang berhubungan dengan permasalahan yang sedang diteliti. 


\section{Populasi dan Sampel}

Populasi adalah keseluruhan dari Subyek penelitian (Arikunto,1998: 115), dalam penelitian ini yang menjadi populasi adalah seluruh mahasiswa IOB dari Fakultas Ekonomi dan Bisnis maupun Fakultas ICT yang masih aktif berkuliah yang diketahui berjumlah sekitar 2500 mahasiswa.

Sampel adalah bagian dari unit populasi. Jumlah sampel dalam penelitian ini sebanyak 104 responden yang terdiri dari mahasiswa IOB yang sedang aktif kuliah, baik itu mahasiswa dari Fakultas Ekonomi dan Bisnis, beserta mahasiswa Fakultas ICT.

Teknik sampling yang digunakan dalam penelitian ini adalah purposive sampling. Jumlah sampel berdasar pendapat Roscoe adalah lebih besar dari 30 dan kurang dari 500 telah mencukupi untuk digunakan dalam sebuah penelitian.

\section{Pengumpulan Data}

Dalam pengumpulan data yang dipergunakan adalah sebagai berikut :

a.Angket cara pengumpulan data dengan penyebaran kuisioner atau daftar pertayaan yang disusun secara sistimatis dengan beberapa pilihan jawaban yang mudah dipahami.

b.Dokumentasi data yang diperoleh dari dalam organisasi yang berkaitan dengan penelitian ini dengan cara mengutip atau menyalin data yang diperlukan.

\section{Instrumen Penelitian}

Instrumen pengumpulan data primer berupa daftar pertanyaan yang dipersiapkan dalam sebuah kuesioner. Materi pertanyaan berhubungan dengan unsur-unsur pengaruh kualitas pelayanan yang menentukan kepuasan dan loyalitas 
mahasiswa pada IOB Timor-Leste. Instrumen yang digunakan dalam sebuah penelitian dapat berupa pertanyaan tertutup atau terbuka yang dapat diberikan langsung pada responden (Sugiyono, 2009: 199). Instrumen yang digunakan pada penelitian ini adalah kuesioner tertutup yang terdiri dari sekumpulan pertanyaan berdasarkan indikator dari masing - masing konstruk. Setiap item pertanyaan diukur dengan menggunakan skala likert dengan 5 kategori dari sangat setuju sampai sangat tidak setuju.

\section{Skala Pengukuran}

Skala yang digunakan adalah skala likert dengan skor adalah sebagai berikut:

Sangat setuju : 5, KurangSetuju : 4, Setuju : 3, Tidak setuju : 2, Sangat tidak setuju : 1

\section{Uji validitas dan uji reliabilitas instrumen}

Data dalam penelitian menjadi tidak berguna bila alat pengukuran yang digunakan tidak memiliki reliabilitas dan validitas yang tinggi, atau dapat diandalkan atau dipercaya. Uji reliabilitas dan validitas memberikan informasi tentang data yang dikumpulkan betul-betul menggambarkan fenomena yang ingin diukur.Uji validitas berguna dilakukan mengetahui apakah pertanyaan-pertanyaan yang telah tercantum pada kuesioner yang harus dibuang atau diganti, karena diangap tidak relevan. Menurut Muhidin dan Abdurahman (2007 dalam Hayati, 2011: 50), banyaknya responden untuk uji coba instrument, belum ada ketentuan yang mensyaratkan, namun disarankan sekitar $20-30$ responden. Suatu instrumen dikatakan validjika memiliki koefisien korelasi antara butir pernyataan dengan skor total dalam instrumen tersebut lebih besar dari 0,30 dengan tingkat 
kesalahan Alpha 0,05.Menurut Aritonang (2007: 136), instrument yang reliable adalah instrument yang dapat memberikan pengukuran yang (relative) sama bila instrument itu digunakan untuk mengukur variable yang sama pada dua atau lebih waktu yang berbeda dalam keadaan yang lebih kurang sama.

Reliabilitas adalah ukuran mengenai konsistensi internal dari indikator indikator sebuah konstruk yang menunjukkan derajat sampai dimana masing masing indikator itu mengindikasikan sebuah konstruk laten (Ferdinand, 2002: 62). Sebuah alat ukur dikatakan reliabel bila nilai Construct reliability $>0.70$ atau variance etract $>0.50$.

\section{Metode Analisis Data}

\section{Deskripsi Variabel penelitian}

Deskripsi variabel penelitian menggambarkan penilaian responden untuk setiap butir-butir pertanyaan yang diajukan dalam kuesioner. Penilaian responden disajikan menurut variabel Keandalan, Daya tanggap, Jaminan, Perhatian, Bukti fisik, Kepuasan dan Loyalitas dengan mengunakan skala pengukuran 1 sampai 5. Untuk menggambarkan penilaian rata-rata responden mengenai variabel-variabel dalam penelitian, hasil jawaban responden disesuaikan dengan desain skala pengukuran yang telah ditetapkan kemudian diformulasikan ke dalam beberapa interval kelas (Suharsono, 2010: 21). Rumus interval kelas adalah sebagai berikut:

$$
\begin{aligned}
& \text { Interval kelas }=\frac{\text { Nilai tertinggi }- \text { nilai terendah }}{\text { Jumlah kelas }} \\
& \text { Interval kelas }=\frac{5-1}{5}=0,8
\end{aligned}
$$


Berdasarkan interval kelas tersebut maka dapat diketahui batasan nilai masingmasing kelas menjadi dasar penentu katagori rata-rata jawaban responden penelitian.

$$
\begin{aligned}
& 1,00-1,79=\text { Sangat tidak baik } \\
& 1,80-2,60=\text { Tidak baik } \\
& 2,60-3,39=\text { Cukup baik } \\
& 3,40-4,19=\text { Baik } \\
& 4,20-4,50=\text { Sangat baik }
\end{aligned}
$$

\section{Analisis SEM (Structural Equation Modeling)}

Penelitian ini dianalisis mengunakan SEM (Structural Equation Modeling) yang didasarkan pada evaluasi atas adanya hubungan saling ketergantungan antar variabel. Menurut Santoso (2011: 5), SEM adalah teknik analisis multivariate yang merupakan kombinasi antara analisis factor dan analisis regresi(korelasi), yang bertujuan untuk menguji hubungan-hubungan antar variabel yang ada pada sebuah model, baik itu antar indikator dengan konstruknya, ataupun hubungan antar konstruk. Secara umum, sebuah model SEM dapat dibagi menjadi dua bagian yaitu : 1) measurement model dan 2) structural model.

\section{HASIL DAN PEMBAHASAN}

\section{Karakteristik Responden}

Karakteristik responden merupakan informasi yang sanggat berharga dalam suatu populasiyang bisa dijelaskan dengan alat uji statistik. Karakteristik responden dalam penelitian ini digambarkan melalui usia, jenis kelamin, jurusan, 
jenjang pendidikan dan semester mahasiswa. Hasil karakteristik responden yang terkumpul melalui kuesioner seperti pada Tabel1 berikut ini.

Tabel 1

Karakteristik Responden

\begin{tabular}{|c|c|c|c|}
\hline \multirow[b]{2}{*}{ No } & \multirow[b]{2}{*}{ Karakteristik Responden } & \multicolumn{2}{|c|}{ Jumlah } \\
\hline & & Orang & Presentase $(\%)$ \\
\hline & Berdasarkan Usia : & & \\
\hline 1 & $17-21$ Tahun & 87 & 83.65 \\
\hline 2 & $22-26$ Tahun & 15 & 14.42 \\
\hline \multirow[t]{3}{*}{3} & $27-31$ Tahun & 2 & 1.93 \\
\hline & Total & 104 & 100 \\
\hline & Berdasarkan Jenis Kelamin : & & \\
\hline 1 & Laki-Laki & 65 & 62.5 \\
\hline \multirow[t]{3}{*}{2} & Perempuan & 39 & 37.5 \\
\hline & Total & 104 & 100 \\
\hline & Berdasarkan Jurusan: & & \\
\hline 1 & Manajemen Umum & 32 & 30.77 \\
\hline 2 & Manajemen Keuangan & 21 & 20.19 \\
\hline 3 & Akuntansi & 10 & 9.62 \\
\hline 4 & Studi Pembangunan & 3 & 2.89 \\
\hline 5 & Manajemen Informatika & 5 & 4.81 \\
\hline 6 & Teknik Informatika & 25 & 24.1 \\
\hline \multirow[t]{4}{*}{7} & Akuntansi Komputer & 7 & 6.74 \\
\hline & Total & 104 & 100 \\
\hline & Berdasarkan Jenjang & & \\
\hline & Pendidikan : & & \\
\hline 1 & D3 & 3 & 2.89 \\
\hline \multirow[t]{3}{*}{2} & $\mathrm{~S} 1$ & 101 & 97.12 \\
\hline & Total & 104 & 100 \\
\hline & Berdasarkan Semester & & \\
\hline 1 & $\mathrm{I}$ & 23 & 22.12 \\
\hline 2 & III & 71 & 68.27 \\
\hline 3 & $\mathrm{~V}$ & 8 & 7.7 \\
\hline \multirow[t]{2}{*}{4} & VII & 2 & 2 \\
\hline & Total & 104 & 100 \\
\hline
\end{tabular}

Sumber : Hasil pengolahan data

\section{1) Uji Validitas dan Reliabilitas Instrumen Penelitian}

Instrumen dalam penelitian dinyatakan valid jika mampu mengukur apa yang seharusnya diukur. Suatu instrumen dikatakan valid jika memiliki koefisien korelasi antara butir pernyataan dengan skor total dalam instrumen tersebut lebih besar dari 0,30 dengan tingkat kesalahan Alpha 0,05.Hasil uji validitas instrumen dapat dilihat pada Tabel 2. 
ISSN : 2337-3067

E-Jurnal Ekonomi dan Bisnis Universitas Udayana 6.8 (2017): 2917-2954

Tabel 2

Rekapitulasi Hasil Uji Reabilitas

\begin{tabular}{|c|c|c|c|c|}
\hline No & Indikator & $\begin{array}{l}\text { Pearson } \\
\text { Correlation } \\
\text { (r) }\end{array}$ & Sig. (2-tailed) & Keterangan \\
\hline 1. & $\mathrm{X}_{1.1}($ Proses belajar $)$ & 0.840 & 0.000 & Valid \\
\hline 2. & $\mathrm{X}_{1.2}$ (Tenaga pengajar handal) & 0.892 & 0.000 & Valid \\
\hline 3. & $\mathrm{X}_{1.3}$ (Pengajar berkualifikasi) & 0.828 & 0.000 & Valid \\
\hline 4. & $\mathrm{X}_{1.4}$ (Staff administrasi handal) & 0.911 & 0.000 & Valid \\
\hline 5. & $\begin{array}{l}\mathrm{X}_{1.5} \text { (Staff administrasi selalu } \\
\text { aktif) }\end{array}$ & 0.847 & 0.000 & Valid \\
\hline 6. & $\mathrm{X}_{2.1}$ (Staff administrasi aktif) & 0.930 & 0.000 & Valid \\
\hline 7. & $\begin{array}{l}\mathrm{X}_{2.2} \text { (Staff administrasi tanggap } \\
\text { merespon mahasiswa) }\end{array}$ & 0.872 & 0.000 & Valid \\
\hline 8. & $\begin{array}{l}\mathrm{X}_{2.3}(\text { Staff administrasi } \\
\text { menangapi masalah } \\
\text { mahasiswa) }\end{array}$ & 0.857 & 0.000 & Valid \\
\hline 9. & $\begin{array}{l}\mathrm{X}_{2.4} \text { (Staff administrasi } \\
\text { membantu mahasiswa) }\end{array}$ & 0.913 & 0.000 & Valid \\
\hline 10. & $\begin{array}{l}\mathrm{X}_{2.5} \text { (Tenaga pengajar } \\
\text { membantu mahasiswa) }\end{array}$ & 0.932 & 0.000 & Valid \\
\hline 11. & $\begin{array}{l}\mathrm{X}_{3.1} \text { (Tenaga pengajar } \\
\text { mengajar dengan metode yang } \\
\text { tepat) }\end{array}$ & 0.736 & 0.000 & Valid \\
\hline 12. & $\mathrm{X}_{3.2}$ (Staff administrasi sopan) & 0.847 & 0.000 & Valid \\
\hline 13. & $\begin{array}{l}\mathrm{X}_{3.3} \text { (Tenaga pengajar } \\
\text { menguasai materi) }\end{array}$ & 0.905 & 0.000 & Valid \\
\hline 14. & $\begin{array}{l}\mathrm{X}_{3.4} \text { (Tenaga pengajar selalu } \\
\text { aktif) } \\
\mathrm{X}_{3.5} \text { (Tenaga pengajar sopan } \\
\text { dan professional) }\end{array}$ & $\begin{array}{l}0.896 \\
0.739\end{array}$ & $\begin{array}{l}0.000 \\
0.000\end{array}$ & $\begin{array}{l}\text { Valid } \\
\text { Valid }\end{array}$ \\
\hline 15. & $\begin{array}{l}\mathrm{X}_{4.1} \text { (Tenaga pengajar } \\
\text { komunikatif) }\end{array}$ & 0.883 & 0.000 & Valid \\
\hline 16. & $\begin{array}{l}\mathrm{X}_{4.2} \text { (Staff administrasi } \\
\text { bersikap professional) }\end{array}$ & 0.882 & 0.000 & Valid \\
\hline 17. & $\begin{array}{l}\mathrm{X}_{4.3} \text { (Staff administrasi } \\
\text { memahami mahasiswa) }\end{array}$ & 0.580 & 0.001 & Valid \\
\hline 18. & $\begin{array}{l}\mathrm{X}_{4.4} \text { (Staff administrasi selalu } \\
\text { membantu) }\end{array}$ & 0.891 & 0.000 & Valid \\
\hline 19. & $\begin{array}{l}\mathrm{X}_{4.5} \text { (Tenaga pengajar selalu } \\
\text { membantu) }\end{array}$ & 0.870 & 0.000 & Valid \\
\hline 20. & $\begin{array}{l}\mathrm{X}_{5.1} \text { (Area kampus dan fasilitas } \\
\text { bersih) }\end{array}$ & 0.865 & 0.000 & Valid \\
\hline 21. & $\begin{array}{l}\mathrm{X}_{5.2} \text { (Peralatan bantu mengajar } \\
\text { lengkap) }\end{array}$ & 0.911 & 0.000 & Valid \\
\hline 22. & $\mathrm{X}_{5.3}$ (Ruangan kelas teratur) & 0.604 & 0.000 & Valid \\
\hline 23. & $\begin{array}{l}\mathrm{X}_{5.4} \text { (Ruangan kelas } \\
\text { mencukupi) }\end{array}$ & 0.799 & 0.000 & Valid \\
\hline 24. & $\begin{array}{l}\mathrm{X}_{5.5} \text { (Staff administrasi ramah } \\
\text { dan sopan) }\end{array}$ & 0.843 & 0.000 & Valid \\
\hline 25. & $\mathrm{Y}_{1.1}$ (Pelayanan umum) & 0.948 & 0.000 & Valid \\
\hline
\end{tabular}




\begin{tabular}{rllll} 
26. & $\mathrm{Y}_{1.2}$ (Kehandalan staff IOB) & 0.957 & 0.000 & Valid \\
27. & $\begin{array}{l}\mathrm{Y}_{1.3} \text { (Fasilitas belajar } \\
\text { mengajar) }\end{array}$ & 0.929 & 0.000 & Valid \\
28. & $\begin{array}{l}\mathrm{Y}_{1.4} \text { (Fasilitas pelengkap } \\
\text { mengajar) }\end{array}$ & 0.948 & 0.000 & Valid \\
29. & $\mathrm{Y}_{1.5}$ (Koleksi referensi belajar) & 0.857 & 0.000 & Valid \\
30. & $\begin{array}{l}\mathrm{Y}_{2.1} \text { (Loyal walau biaya studi } \\
\text { naik) }\end{array}$ & 0.943 & 0.000 & Valid \\
31. & $\begin{array}{l}\text { Y } \\
\text { rekomendasi) }\end{array}$ & 0.915 & 0.000 & Valid \\
\hline Sumber : Hasil pengolahan data & & &
\end{tabular}

Uji Reliabilitas terhadap instrumen penelitian ini menggunakan nilai Alpha Cronbach, yakni untuk mengetahui unidimensionalitas butir-butir pernyataan terhadap variabel laten yang diteliti (Kehandalan, Daya tanggap, Jaminan, Perhatian, Bukti fisik, Kepuasan dan Loyalitas). Nilai Alpha Cronbach dinyatakan reliabel jika nilainya lebih besar atau sama dengan 0,60 (Ghozali, 2004).

\section{Tabel 3}

Tabel rekapitulasi Hasil Uji Reliabilitas

\begin{tabular}{|c|c|c|c|}
\hline No & Variabel & Alpha & Keterangan \\
\hline 1 & Kehandalan & 0,910 & Reliabel \\
\hline 2 & Daya tanggap & 0,936 & Reliabel \\
\hline 3 & Jaminan & 0,883 & Reliabel \\
\hline 4 & Perhatian & 0,865 & Reliabel \\
\hline 5 & Bukti fisik & 0,867 & Reliabel \\
\hline 6 & Kepuasan & 0,958 & Reliabel \\
\hline 8 & Loyalitas & 0,834 & Reliabel \\
\hline
\end{tabular}

Sumber : Hasil pengolahan data

\section{2) Deskripsi Variabel Penelitian}

Deskripsi variabel penelitian menggambarkan penilaian responden untuk setiap butir-butir pertanyaan yang diajukan dalam kuesioner. Penilaian responden dasajikan menurut variabel Kehandalan, Daya tanggap, Jaminan, Perhatian, Bukti fisik, Kepuasan dan Loyalitas dengan mengunakan skala pengukuran 1 sampai 5. Untuk menggambarkan penilaian rata-rata responden mengenai variabel-variabel 
dalam penelitian, hasil jawaban responden disesuaikan dengan desain skala pengukuran yang telah ditetapkan kemudian diformulasikan ke dalam beberapa interval kelas (Suharsono, 2010:21). Rumus interval kelas adalah sebagai berikut:

$$
\begin{aligned}
& \text { Interval kelas }=\frac{\text { Nilai tertinggi }- \text { nilai terendah }}{\text { Jumlah kelas }} \\
& \text { Interval kelas }=\frac{5-1}{5}=0,8
\end{aligned}
$$

Berdasarkan interval kelas tersebut maka dapat diketahui batasan nilai masingmasing kelas menjadi dasar penentu katagori rata-rata jawaban responden penelitian.

$$
\begin{aligned}
1,00-1,79 & =\text { Sangat tidak baik } \\
1,80-2,59 & =\text { Tidak baik } \\
2,60-3,39 & =\text { Cukup baik } \\
3,40-4,19 & =\text { Baik } \\
4,20-5,00 & =\text { Sangat baik }
\end{aligned}
$$

Berdasarkan hasil analisis deskriptif, maka pada bagian berikut ini diuraikan secara berturut-turut variabel Kualitas pelayanan (X), Kepuasan mahasiswa (Y1) dan Loyalitas mahasiswa (Y2).

\section{(1) Deskripsi Variabel Kualitas Peayanan (X),}

Hasil analisis deskriptif variabelKualitas Layanan (X)berupa proporsi jawaban responden pada alternatif jawaban untuk setiap butir pertanyaan, nilai skor rata-rata setiap butir dan nilai rata-rata skor setiap indikator serta nilai skor rata-rata keseluruhan untuk variabel.Dengan memperhatikan informasi tersebut 
dapat diketahui bahwa kualitas layanan tergolong dipersepsikan baik oleh respondendengan nilai rata-rata di atas 3,40.

Tabel 4

Deskripsi Variabel Kualitas Peayanan (X)

\begin{tabular}{|c|c|c|c|c|c|c|c|c|}
\hline \multirow[t]{2}{*}{ Indikator } & \multicolumn{5}{|c|}{ Skor dengan jawaban } & \multirow{2}{*}{$\begin{array}{l}\text { Jumlah } \\
\text { Skor }\end{array}$} & \multirow{2}{*}{$\begin{array}{l}\text { Rata- } \\
\text { Rata }\end{array}$} & \multirow[t]{2}{*}{ Keterangan } \\
\hline & 1 & 2 & 3 & 4 & 5 & & & \\
\hline $\mathrm{X}_{1.1}$ (Proses belajar) & 0 & 11 & 24 & 31 & 38 & 408 & 3.92 & Baik \\
\hline $\mathrm{X}_{1.2}$ (Tenaga pengajar handal) & 0 & 16 & 20 & 31 & 37 & 401 & 3.86 & Baik \\
\hline $\mathrm{X}_{1.3}$ (Pengajar berkualifikasi) & 2 & 13 & 15 & 28 & 46 & 415 & 3.99 & Baik \\
\hline $\mathrm{X}_{1.4}($ Staff administrasi) & 6 & 15 & 12 & 35 & 36 & 392 & 3.77 & Baik \\
\hline $\mathrm{X}_{1.5}$ (Staff administrasi aktif) & 4 & 11 & 22 & 29 & 38 & 398 & 3.83 & Baik \\
\hline $\mathrm{X}_{2.1}$ (Staff administrasi aktif) & 2 & 17 & 21 & 32 & 32 & 387 & 3.72 & Baik \\
\hline $\begin{array}{c}\mathrm{X}_{2.2} \text { (Staff administrasi } \\
\text { tanggap merespon } \\
\text { mahasiswa) }\end{array}$ & 1 & 22 & 24 & 30 & 27 & 372 & 3.58 & Baik \\
\hline $\begin{array}{l}\mathrm{X}_{2.3}(\text { Staff administrasi } \\
\text { menangapi masalah } \\
\text { mahasiswa) }\end{array}$ & 1 & 10 & 28 & 39 & 26 & 391 & 3.76 & Baik \\
\hline $\begin{array}{l}\mathrm{X}_{2.4} \text { (Staff administrasi } \\
\text { membantu mahasiswa) }\end{array}$ & 4 & 20 & 15 & 24 & 41 & 390 & 3.75 & Baik \\
\hline $\begin{array}{l}\mathrm{X}_{2.5} \text { (Tenaga pengajar } \\
\text { membantu mahasiswa) }\end{array}$ & 2 & 22 & 17 & 20 & 43 & 392 & 3.77 & Baik \\
\hline $\begin{array}{l}\mathrm{X}_{3.1} \text { (Tenaga pengajar } \\
\text { mengajar dengan metode } \\
\text { yang tepat) }\end{array}$ & 1 & 14 & 17 & 27 & 45 & 413 & 3.97 & Baik \\
\hline $\mathrm{X}_{3.2}$ (Staff administrasi sopan) & 2 & 12 & 24 & 30 & 36 & 398 & 3.83 & Baik \\
\hline $\begin{array}{l}\mathrm{X}_{3.3} \text { (Tenaga pengajar } \\
\text { menguasai materi) }\end{array}$ & 0 & 10 & 21 & 24 & 49 & 424 & 4.08 & Baik \\
\hline $\begin{array}{l}\mathrm{X}_{3.4} \text { (Tenaga pengajar selalu } \\
\text { aktif) }\end{array}$ & 3 & 8 & 22 & 20 & 51 & 420 & 4.04 & Baik \\
\hline $\begin{array}{c}\mathrm{X}_{3.5} \text { (Tenaga pengajar sopan } \\
\text { dan professional) }\end{array}$ & 3 & 9 & 21 & 30 & 41 & 409 & 3.93 & Baik \\
\hline $\begin{array}{l}\mathrm{X}_{4.1} \text { (Tenaga pengajar } \\
\text { komunikatif) }\end{array}$ & 4 & 13 & 21 & 22 & 44 & 401 & 3.86 & Baik \\
\hline $\begin{array}{l}\mathrm{X}_{4.2}(\text { Staff administrasi } \\
\text { bersikap professional })\end{array}$ & 5 & 14 & 25 & 22 & 38 & 386 & 3.71 & Baik \\
\hline $\begin{array}{l}\mathrm{X}_{4.3} \text { (Staff administrasi } \\
\text { memahami mahasiswa) }\end{array}$ & 5 & 23 & 13 & 27 & 36 & 378 & 3.63 & Baik \\
\hline $\begin{array}{l}\mathrm{X}_{4.4} \text { (Staff administrasi selalu } \\
\text { membantu) }\end{array}$ & 4 & 13 & 19 & 16 & 52 & 411 & 3.95 & Baik \\
\hline $\begin{array}{l}\mathrm{X}_{4.5} \text { (Tenaga pengajar selalu } \\
\text { membantu) }\end{array}$ & 1 & 13 & 22 & 25 & 43 & 408 & 3.92 & Baik \\
\hline $\begin{array}{l}\mathrm{X}_{5.1} \text { (Area kampus dan } \\
\text { fasilitas bersih) }\end{array}$ & 2 & 16 & 16 & 25 & 45 & 407 & 3.91 & Baik \\
\hline $\begin{array}{l}\mathrm{X}_{5.2} \text { (Peralatan bantu mengajar } \\
\text { lengkap) }\end{array}$ & 4 & 14 & 19 & 31 & 36 & 393 & 3.78 & Baik \\
\hline
\end{tabular}




\begin{tabular}{lllllllll}
$\mathrm{X}_{5.3}$ (Ruangan kelas teratur) & 2 & 16 & 23 & 26 & 37 & 392 & 3.77 & Baik \\
$\begin{array}{l}\mathrm{X}_{5.4} \text { (Ruangan kelas } \\
\text { mencukupi) }\end{array}$ & 5 & 16 & 15 & 20 & 48 & 402 & 3.87 & Baik \\
$\begin{array}{l}\mathrm{X}_{5.5} \text { (Staff administrasi ramah } \\
\text { dan sopan) }\end{array}$ & 4 & 17 & 16 & 29 & 38 & 392 & 3.77 & Baik \\
\hline
\end{tabular}

Sumber : Hasil pengolahan data

\section{(2).Deskripsi Variabel Kepuasan Mahasiswa (Y1)}

Tabel 5

Deskripsi Variabel Kepuasan Mahasiswa (Y1)

\begin{tabular}{|c|c|c|c|c|c|c|c|c|}
\hline \multirow[t]{2}{*}{ Indikator } & \multicolumn{5}{|c|}{ Frekuensi Jawaban } & \multirow{2}{*}{$\begin{array}{c}\text { Jumlah } \\
\text { Skor }\end{array}$} & \multirow{2}{*}{$\begin{array}{l}\text { Rata- } \\
\text { Rata }\end{array}$} & \multirow[b]{2}{*}{ Keterangan } \\
\hline & 1 & 2 & 3 & 4 & 5 & & & \\
\hline $\mathrm{Y}_{1.1}$ (Pelayanan umum) & 0 & 13 & 23 & 29 & 39 & 406 & 3.90 & Baik \\
\hline $\mathrm{Y}_{1.2}($ Kehandalan staff IOB) & 5 & 12 & 24 & 31 & 32 & 385 & 3.70 & Baik \\
\hline $\mathrm{Y}_{1.3}$ (Fasilitas belajar mengajar) & 3 & 11 & 19 & 21 & 50 & 416 & 4.00 & Baik \\
\hline $\begin{array}{l}\mathrm{Y}_{1.4} \text { (Fasilitas pelengkap } \\
\text { mengajar) }\end{array}$ & 5 & 9 & 26 & 16 & 48 & 405 & 3.89 & Baik \\
\hline $\mathrm{Y}_{1.5}$ (Koleksi referensi belajar) & 2 & 13 & 17 & 35 & 37 & 404 & 3.88 & Baik \\
\hline \multicolumn{7}{|c|}{ Rata-Rata $\left(\mathrm{Y}_{1}\right)$} & 3.88 & Baik \\
\hline
\end{tabular}

Sumber : Hasil pengolahan data

\section{(3). Deskripsi Variabel Loyalitas Mahasiswa (Y2)}

Tabel 6

Deskripsi Variabel Loyalitas Mahasiswa (Y2)

\begin{tabular}{|c|c|c|c|c|c|c|c|c|}
\hline \multirow[t]{2}{*}{ Indikator } & \multicolumn{5}{|c|}{ Frekuensi Jawaban } & \multirow{2}{*}{$\begin{array}{c}\text { Jumlah } \\
\text { Skor }\end{array}$} & \multirow{2}{*}{$\begin{array}{l}\text { Rata- } \\
\text { Rata }\end{array}$} & \multirow[b]{2}{*}{ Keterangan } \\
\hline & 1 & 2 & 3 & 4 & 5 & & & \\
\hline $\begin{array}{l}\mathrm{Y}_{2.1} \text { (Loyal walau biaya studi } \\
\text { naik) }\end{array}$ & 7 & 16 & 17 & 20 & 44 & 390 & 3.75 & Baik \\
\hline $\begin{array}{l}\mathrm{Y}_{2.2} \text { (memberikan } \\
\text { rekomendasi) }\end{array}$ & 2 & 20 & 14 & 26 & 42 & 398 & 3.83 & Baik \\
\hline \multicolumn{7}{|c|}{ Rata-Rata $\left(\mathrm{Y}_{2}\right)$} & 3.79 & Baik \\
\hline
\end{tabular}

Sumber : Hasil pengolahan data

\section{3). Model Pengukuran (Measurement Model)}

Uji measurement model terdiri atas 2 (dua) pengujian yaitu uji kecocokan model (goodness of fit model) dan uji validitas model pengukuran. Uji kecocokan digunakan untuk mengetahui apakah model yang terbentuk sudah sesuai dengan data yang tersedia. Kemudian validitas model pengukuran untuk mengetahui apakah semua muatan faktor (loading factor) mempunyai validitas yang baik.

\section{(1). Uji Kecocokan dan Uji Muatan Faktor Variabel Kehandalan (x1)}


Tabel 7

Uji Kecocokan Variabel kehandalan

\begin{tabular}{cccc}
\hline Goodness of Fit Index & Cut of Value & Hasil Model & Keterangan \\
\hline Probability $(P)$ & $\geq 0,05$ & 0,225 & Baik \\
$X^{2}$-Chi-Square & $<11,07$ & 6,568 & Baik \\
& $(\mathrm{df}=5, \alpha=0,05)$ & & \\
CMIN/DF & $\leq 2,00$ & 1,314 & Baik \\
GFI & $\geq 0,90$ & 0,983 & Baik \\
TLI & $\geq 0,95$ & 0,983 & Baik \\
CFI & $\geq 0,95$ & 0,992 & Baik \\
RMSEA & $\leq 0,08$ & 0,055 & Baik \\
AGFI & $\geq 0,90$ & 0,924 & Baik \\
\hline
\end{tabular}

Sumber : Hasil pengolahan data

Tabel 8

Uji Muatan Faktor Variabel kehandalan

\begin{tabular}{lllrrrr}
\hline & & $\begin{array}{c}\text { Estimate } \\
\text { Unstandardize }\end{array}$ & S.E. & $\begin{array}{c}\text { Estimate } \\
\text { Standardize }\end{array}$ & C.R. & P \\
\hline $\mathrm{X}_{1.1}<---$ & Kehandalan & 1.020 & .192 & .698 & 5.314 & $* * * *$ \\
$\mathrm{X}_{1.2}<---$ & Kehandalan & 1.243 & .205 & .801 & 6.059 & $* * *$ \\
$\mathrm{X}_{1.3}<---$ & Kehandalan & 1.192 & .215 & .731 & 5.551 & $* * *$ \\
$\mathrm{X}_{1.4}<---$ & Kehandalan & 1.360 & .239 & .764 & 5.696 & $* * *$ \\
$\mathrm{X}_{1.5}<---$ & Kehandalan & 1.000 & & .600 & & \\
\hline \multicolumn{5}{l}{ Sumber : Hasil pengolahan data }
\end{tabular}

(2). Uji Kecocokan dan Uji Muatan Faktor Variabel Daya Tanggap (x2)

Tabel 9

Uji Kecocokan Variabel Daya Tanggap

\begin{tabular}{cccc}
\hline Goodness of Fit Index & Cut of Value & Hasil Model & Keterangan \\
\hline Probability $(P)$ & $\geq 0,05$ & 0,197 & Baik \\
$X^{2}$-Chi-Square & $<11,07$ & 7,335 & Baik \\
& $(\mathrm{df}=5, \alpha=0,05)$ & & \\
CMIN/DF & $\leq 2,00$ & 1,467 & Baik \\
GFI & $\geq 0,90$ & 0,973 & Baik \\
TLI & $\geq 0,95$ & 0,984 & Baik \\
CFI & $\geq 0,95$ & 0,992 & Baik \\
RMSEA & $\leq 0,08$ & 0,067 & Baik \\
AGFI & $\geq 0,90$ & 0,920 & Baik \\
\hline
\end{tabular}

Sumber : Hasil pengolahan data

Tabel 10

Uji Muatan Faktor Variabel Daya Tanggap

\begin{tabular}{lrrrrrr}
\hline & & $\begin{array}{r}\text { Estimate } \\
\text { Unstandardize }\end{array}$ & S.E. & $\begin{array}{r}\text { Estimate } \\
\text { Standardize }\end{array}$ & C.R. & P \\
\hline $\mathrm{X}_{2.1}<---$ & Daya tanggap & .867 & .101 & .781 & 8.590 & $* * *$ \\
$\mathrm{X}_{2.2}<---$ & Daya tanggap & .853 & .100 & .773 & 8.521 & $* * *$ \\
$\mathrm{X}_{2.3}<---$ & Daya tanggap & .738 & .085 & .772 & 8.721 & $* * *$ \\
$\mathrm{X}_{2.4}<---$ & Daya tanggap & 1.057 & .111 & .846 & 9.483 & $* * *$ \\
$\mathrm{X}_{2.5}<---$ & Daya tanggap & 1.000 & & .813 & \\
\hline
\end{tabular}

Sumber : Hasil pengolahan data 


\section{(3). Uji Kecocokan dan Uji Muatan Faktor Variabel Jaminan (x3)}

Tabel 11

Uji Kecocokan Variabel Jaminan

\begin{tabular}{cccc}
\hline Goodness of Fit Index & Cut of Value & Hasil Model & Keterangan \\
\hline Probability $(P)$ & $\geq 0,05$ & 0,091 & Baik \\
$X^{2}$-Chi-Square & $<11,07$ & 9,484 & Baik \\
& $(\mathrm{df}=5, \alpha=0,05)$ & & \\
CMIN/DF & $\leq 2,00$ & 1,897 & Baik \\
GFI & $\geq 0,90$ & 0,962 & Baik \\
TLI & $\geq 0,95$ & 0,964 & Baik \\
CFI & $\geq 0,95$ & 0,982 & Baik \\
RMSEA & $\leq 0,08$ & 0,093 & Marginal \\
AGFI & $\geq 0,90$ & 0,886 & Marginal \\
\hline
\end{tabular}

Sumber : Hasil pengolaan data

Tabel 12

Uji Muatan Faktor Variabel Jaminan

\begin{tabular}{llllrrc}
\hline & & Estimate & S.E. & Estimate & C.R. & $\mathrm{P}$ \\
\hline $\mathrm{X}_{3.1}<---$ & Jaminan & 1.186 & .186 & .764 & 6.383 & $* * *$ \\
$\mathrm{X}_{3.2}<---$ & Jaminan & 1.109 & .174 & .725 & 6.369 & $* * *$ \\
$\mathrm{X}_{3.3}<---$ & Jaminan & 1.213 & .176 & .841 & 6.891 & $* * *$ \\
$\mathrm{X}_{3.4}<---$ & Jaminan & 1.341 & .190 & .847 & 7.066 & $* * *$ \\
$\mathrm{X}_{3.5}<---$ & Jaminan & 1.000 & \multicolumn{7}{c}{.650} \\
\hline \multicolumn{5}{l}{ Sumber : Hasil pengolahan data }
\end{tabular}

Sumber : Hasil pengolahan data

\section{(4). Uji Kecocokan dan Uji Muatan Faktor Variavel Perhatian (x4)}

Tabel 13

Uji Kecocokan Variabel Perhatian

\begin{tabular}{cccc}
\hline Goodness of Fit Index & Cut of Value & Hasil Model & Keterangan \\
\hline Probability $(P)$ & $\geq 0,05$ & 0,063 & Baik \\
$X^{2}$-Chi-Square & $<11,07$ & 10,470 & Baik \\
& $(\mathrm{df}=5, \alpha=0,05)$ & & \\
CMIN/DF & $\leq 2,00$ & 2,094 & Marginal \\
GFI & $\geq 0,90$ & 0,963 & Baik \\
TLI & $\geq 0,95$ & 0,971 & Baik \\
CFI & $\geq 0,95$ & 0,986 & Baik \\
RMSEA & $\leq 0,08$ & 0,103 & Marginal \\
AGFI & $\geq 0,90$ & 0,889 & Marginal \\
\hline
\end{tabular}

Sumber : Hasil pengolaan data

Tabel 14

Uji Muatan Faktor Variabel Perhatian

\begin{tabular}{llrrrrr}
\hline & & $\begin{array}{c}\text { Estimate } \\
\text { Unstandardize }\end{array}$ & S.E. & $\begin{array}{r}\text { Estimate } \\
\text { Standardize }\end{array}$ & C.R. & P \\
\hline $\mathrm{X}_{4.1}<---$ & Perhatian & .997 & .087 & .828 & 11.459 & $* * *$ \\
$\mathrm{X}_{4.2}<---$ & Perhatian & 1.088 & .078 & .890 & 13.946 & $* * *$ \\
$\mathrm{X}_{4.3}<---$ & Perhatian & .837 & .107 & .651 & 7.805 & $* * *$ \\
\hline
\end{tabular}




\begin{tabular}{llrrrrr}
\hline & & $\begin{array}{c}\text { Estimate } \\
\text { Unstandardize }\end{array}$ & S.E. & $\begin{array}{r}\text { Estimate } \\
\text { Standardize }\end{array}$ & C.R. & P \\
\hline $\mathrm{X}_{4.4}<---$ & Perhatian & 1.068 & .084 & .865 & 12.735 & $* * *$ \\
$\mathrm{X}_{4.5}<---$ & Perhatian & 1.000 & & .911 & & \\
\hline
\end{tabular}

Sumber : Hasil pengolahan data

\section{(5). Uji Kecocokan dan Uji Muatan Faktor Variavel Bukti Fisik (x5)}

Tabel 15

Uji Kecocokan Variabel Bukti Fisik

\begin{tabular}{cccc}
\hline Goodness of Fit Index & Cut of Value & Hasil Model & Keterangan \\
\hline Probability $(P)$ & $\geq 0,05$ & 0,093 & Baik \\
$X^{2}$-Chi-Square & $<11,07(\mathrm{df}=5, \alpha=0,05)$ & 9,445 & Baik \\
CMIN/DF & $\leq 2,00$ & 1,889 & Baik \\
GFI & $\geq 0,90$ & 0,967 & Baik \\
TLI & $\geq 0,95$ & 0,969 & Baik \\
CFI & $\geq 0,95$ & 0,985 & Baik \\
RMSEA & $\leq 0,08$ & 0,093 & Marginal \\
AGFI & $\geq 0,90$ & 0,900 & Baik \\
\hline Sumber : Hasil pengolaan data & & &
\end{tabular}

Tabel 16

Uji Muatan Faktor Variabel Bukti Fisik

\begin{tabular}{llrrrrrr}
\hline & & & $\begin{array}{r}\text { Estimate } \\
\text { Unstandardize }\end{array}$ & S.E. & $\begin{array}{c}\text { Estimate } \\
\text { Standardize }\end{array}$ & C.R. & P \\
\hline $\mathrm{X}_{5.1}<---$ & Bukti Fisik & .952 & .102 & .813 & 9.324 & $* * *$ \\
$\mathrm{X}_{5.2}<---$ & Bukti Fisik & .997 & .098 & .852 & 10.139 & $* * *$ \\
$\mathrm{X}_{5.3}<---$ & Bukti Fisik & .777 & .108 & .677 & 7.205 & $* * *$ \\
$\mathrm{X}_{5.4}<---$ & Bukti Fisik & 1.032 & .111 & .806 & 9.317 & $* * *$ \\
$\mathrm{X}_{5.5}<---$ & Bukti Fisik & 1.000 & & .825 & & \\
\hline
\end{tabular}

Sumber : Hasil pengolaan data

(6). Uji Kecocokan dan Uji Muatan Faktor Variavel Kepuasan mahasiswa (y1)

Tabel 17

Uji Kecocokan Variabel Kepuasan Mahasiswa

\begin{tabular}{cccc}
\hline Goodness of Fit Index & Cut of Value & Hasil Model & Keterangan \\
\hline Probability $(P)$ & $\geq 0,05$ & 0,662 & Baik \\
$X^{2}$-Chi-Square & $<11,07$ & 3,247 & Baik \\
& $(\mathrm{df}=5, \alpha=0,05)$ & & \\
CMIN/DF & $\leq 2,00$ & 0,649 & Baik \\
GFI & $\geq 0,90$ & 0,987 & Baik \\
TLI & $\geq 0,95$ & 1,010 & Baik \\
CFI & $\geq 0,95$ & 1,000 & Baik \\
RMSEA & $\leq 0,08$ & 0,000 & Baikl \\
AGFI & $\geq 0,90$ & 0,962 & Baik \\
\hline
\end{tabular}

Sumber : Hasil pengolaan data 
Tabel 18

Uji Muatan faktor Variabel Kepuasan Mahasiswa

\begin{tabular}{|c|c|c|c|c|c|c|}
\hline & & Estimate & Estimate & S.E. & C.R. & $\mathrm{P}$ \\
\hline$Y_{1.2}<---$ & Kepuasan & 1.223 & .852 & .140 & 8.744 & $* * *$ \\
\hline$Y_{1.3}<---$ & Kepuasan & 1.253 & .872 & .138 & 9.105 & $* * *$ \\
\hline$Y_{1.1}<---$ & Kepuasan & 1.101 & .853 & .125 & 8.798 & $* * *$ \\
\hline$Y_{1.4}<---$ & Kepuasan & 1.260 & .836 & .147 & 8.600 & $* * *$ \\
\hline$Y_{1.5}<---$ & Kepuasan & 1.000 & .743 & & & \\
\hline
\end{tabular}

Sumber : Hasil pengolaan data

\section{(7). Uji Kesesuaian Model Keseluruhan}

Dengan telah diterimanya masing-masing indikator yang digunakan untuk mendefinisikan variabel laten (konstruk) berdasarkan hasil estimasi model pengukuran yang dilakukan dengan teknik comfirmatory factor analysis, maka estimasi dilanjutkan pada estimasi model persamaan struktural dengan teknik full model analysis. Estimasi ini ditujukan untuk melihat kesesuaian model dan hubungan kausalitas yang terjadi pada suatu hubungan yang berjenjang. Hasil estimasi model persamaan struktural dapat dilihat pada Gambar 2. 


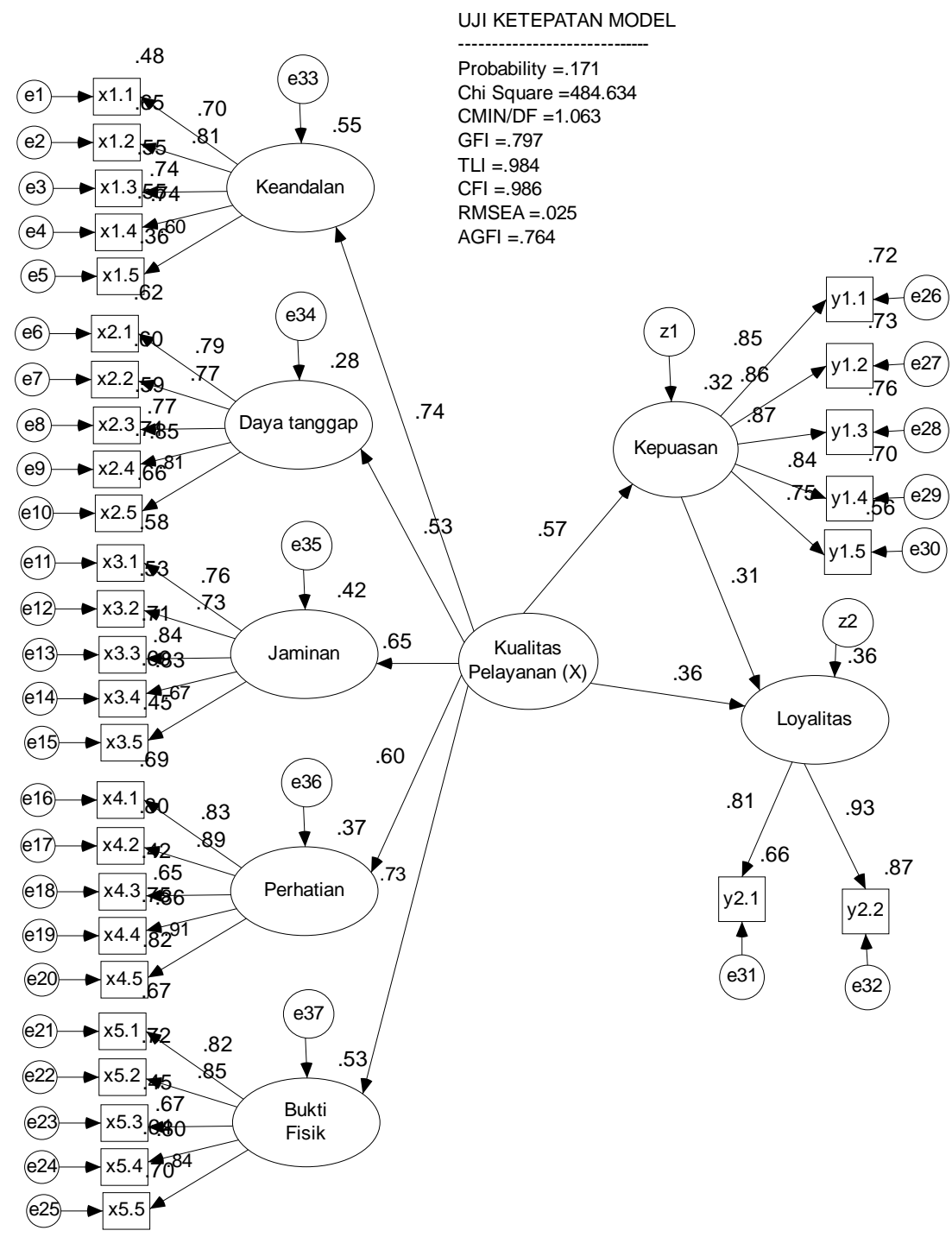

Gambar 2 Model Persamaam Struktural Pengaruh Kualitas Pelayanan terhadap Kepuasan dan Loyalitas

Sumber : Hasil pengolaan data

\section{Tabel 19}

Goodness of Fit Indexes Model Keseluruhan

\begin{tabular}{cccc}
\hline Goodness of Fit Index & Cut of Value & Hasil Model & Keterangan \\
\hline Probability $(P)$ & $\geq 0,05$ & 0.171 & Baik \\
$X^{2}$-Chi-Square & $<506,784$ & 484,638 & Baik \\
& $(\mathrm{df}=456, \alpha=0,05)$ & & \\
CMIN/DF & $\leq 2,00$ & 1.063 & Baik \\
GFI & $\geq 0,90$ & 0.797 & Marginal \\
TLI & $\geq 0,95$ & 0.984 & Baik \\
CFI & $\geq 0,95$ & 0.986 & Baik \\
RMSEA & $\leq 0,08$ & 0.025 & Baik \\
AGFI & $\geq 0,90$ & 0.764 & Marginal \\
\hline
\end{tabular}

Sumber: Ferdinand (2002) dan Hasil Analisis SEM 


\section{(8) Uji Kausalitas}

Uji kausalitas bertujuan untuk mengetahui hubungan kausalitas antar konstruk eksogen dengan konstruk endogen dalam suatu penelitian. Hasil uji regression weightdapat dilihat pada Tabel 20. Hasil dari uji kausalitas menunjukkan bahwa nilai critical ratio(C.R) tidak sama dengan nol, dan pada nilai $\mathrm{P}<0,05$. Dengan demikian dapat dinyatakan bahwa terdapat hubungan nyata antara variable kualitas pelayanan dengan kepuasan dan loyalitas.

Tabel 20

Estimasi Parameter Regression weight Full Model

\begin{tabular}{|c|c|c|c|c|c|c|c|}
\hline & & & Estimate & S.E. & C.R. & $\mathrm{P}$ & Label \\
\hline Kepuasan & $<---$ & Kualitas Pelayanan & .628 & .150 & 4.188 & $* * *$ & par_2 \\
\hline Loyalitas & $<---$ & Kualitas Pelayanan & .550 & .218 & 2.523 & .012 & par_3 \\
\hline Loyalitas & $<---$ & Kepuasan & .436 & .173 & 2.526 & .012 & par_8 \\
\hline Jaminan & $<---$ & Kualitas Pelayanan & .644 & .156 & 4.131 & $* * *$ & par_29 \\
\hline Perhatian & $<---$ & Kualitas Pelayanan & .820 & .180 & 4.546 & $* * *$ & par_30 \\
\hline Bukti Fisik & $<---$ & Kualitas Pelayanan & 1.000 & & & & \\
\hline Daya tanggap & $<---$ & Kualitas Pelayanan & .723 & .184 & 3.920 & $* * *$ & par_31 \\
\hline Kehandalan & $<---$ & Kualitas Pelayanan & .696 & .163 & 4.263 & $* * *$ & par_32 \\
\hline y1.2 & $<---$ & Kepuasan & 1.221 & .137 & 8.884 & $* * *$ & par_1 \\
\hline y1.3 & $<---$ & Kepuasan & 1.245 & .135 & 9.203 & $* * *$ & par_4 \\
\hline y1.1 & $<---$ & Kepuasan & 1.087 & .123 & 8.838 & $* * *$ & par_5 \\
\hline x1.1 & $<---$ & Kehandalan & 1.014 & .187 & 5.417 & $* * *$ & par_6 \\
\hline y1.4 & $<---$ & Kepuasan & 1.251 & .144 & 8.686 & $* * *$ & par_7 \\
\hline y2.2 & $<---$ & Loyalitas & 1.000 & & & & \\
\hline y2.1 & $<---$ & Loyalitas & .954 & .136 & 7.015 & $* * *$ & par_9 \\
\hline $\mathrm{x} 1.2$ & $<---$ & Kehandalan & 1.251 & .202 & 6.185 & $* * *$ & par_10 \\
\hline $\mathrm{x} 1.3$ & $<---$ & Kehandalan & 1.203 & .211 & 5.698 & $* * *$ & par_11 \\
\hline x1.4 & $<---$ & Kehandalan & 1.321 & .230 & 5.742 & $* * *$ & par_12 \\
\hline $\mathrm{x} 1.5$ & $<---$ & Kehandalan & 1.000 & & & & \\
\hline $\mathrm{x} 2.1$ & $<---$ & Daya tanggap & .873 & .100 & 8.687 & $* * *$ & par_13 \\
\hline $\mathrm{x} 2.2$ & $<---$ & Daya tanggap & .855 & .100 & 8.586 & $* * *$ & par_14 \\
\hline $\mathrm{x} 2.3$ & $<---$ & Daya tanggap & .732 & .085 & 8.658 & $* * *$ & par_15 \\
\hline $\mathrm{x} 2.4$ & $<---$ & Daya tanggap & 1.055 & .111 & 9.537 & $* * *$ & par_16 \\
\hline $\mathrm{x} 2.5$ & $<---$ & Daya tanggap & 1.000 & & & & \\
\hline x3.1 & $<---$ & Jaminan & 1.153 & .175 & 6.580 & $* * *$ & par_17 \\
\hline x3.2 & $<---$ & Jaminan & 1.084 & .165 & 6.587 & $* * *$ & par_18 \\
\hline x3.3 & $<---$ & Jaminan & 1.180 & .165 & 7.138 & $* * *$ & par_19 \\
\hline x3.4 & $<---$ & Jaminan & 1.281 & .177 & 7.225 & $* * *$ & par_20 \\
\hline$x 3.5$ & $<---$ & Jaminan & 1.000 & & & & \\
\hline $\mathrm{x} 4.1$ & $<---$ & Perhatian & 1.007 & .087 & 11.558 & $* * *$ & par_21 \\
\hline $\mathrm{x} 4.2$ & $<---$ & Perhatian & 1.096 & .079 & 13.960 & $* * *$ & par_22 \\
\hline
\end{tabular}




\begin{tabular}{|c|c|c|c|c|c|c|c|}
\hline & & & Estimate & S.E. & C.R. & $P$ & Label \\
\hline $\mathrm{x} 4.3$ & $<--$ & Perhatian & .836 & .108 & 7.734 & $* * *$ & par_23 \\
\hline $\mathrm{x} 4.4$ & $<--$ & Perhatian & 1.072 & .084 & 12.698 & $* * *$ & par_24 \\
\hline $\mathrm{x} 4.5$ & $<--$ & Perhatian & 1.000 & & & & \\
\hline$\times 5.1$ & $<---$ & Bukti Fisik & 947 & .099 & 9.609 & $* * *$ & par_25 \\
\hline$\times 5.2$ & $<--$ & Bukti Fisik & .978 & .095 & 10.296 & $* * *$ & par_26 \\
\hline $\mathrm{x} 5.3$ & $<---$ & Bukti Fisik & .760 & .105 & 7.237 & $* * *$ & par_27 \\
\hline x5.4 & $<--$ & Bukti Fisik & 1.009 & .107 & 9.408 & $* * *$ & par_28 \\
\hline$\times 5.5$ & $<--$ & Bukti Fisik & 1.000 & & & & \\
\hline y1.5 & & Kepuasan & 1.000 & & & & \\
\hline
\end{tabular}

Sumber : Hasil Pengolahan Data

\section{Hasil Pengujian Hipotesis}

Hipotesis diuji dengan t-test pada masing-masing jalur pengaruh langsung secara parsial. Hasil analisis secara ringkas analisis jalur dapat dilihat pada Tabel 21 menyajikan hasil pengujian hipotesis pengaruh langsung

Tabel 21

Hasil Pengujian Hipotesis

\begin{tabular}{lllrl}
\hline & & $p$-value & $\begin{array}{c}\text { Estimate } \\
\text { Standarized }\end{array}$ & Keterangan \\
& & \multicolumn{4}{c}{} \\
\hline Kepuasan $<---$ & Kualitas Pelayanan & 0,000 & .567 & Signifikan \\
Loyalitas $<---$ & Kualitas Pelayanan & 0,000 & .359 & Signifikan \\
Loyalitas $<---$ & Kepuasan & 0,000 & .315 & Signifikan \\
\hline Sumber : Hasil pengolahan data & & &
\end{tabular}

Hasil pengujian hipotesis jalur-jalur pengaruh langsung juga dapat dilihat pada gambar 3.

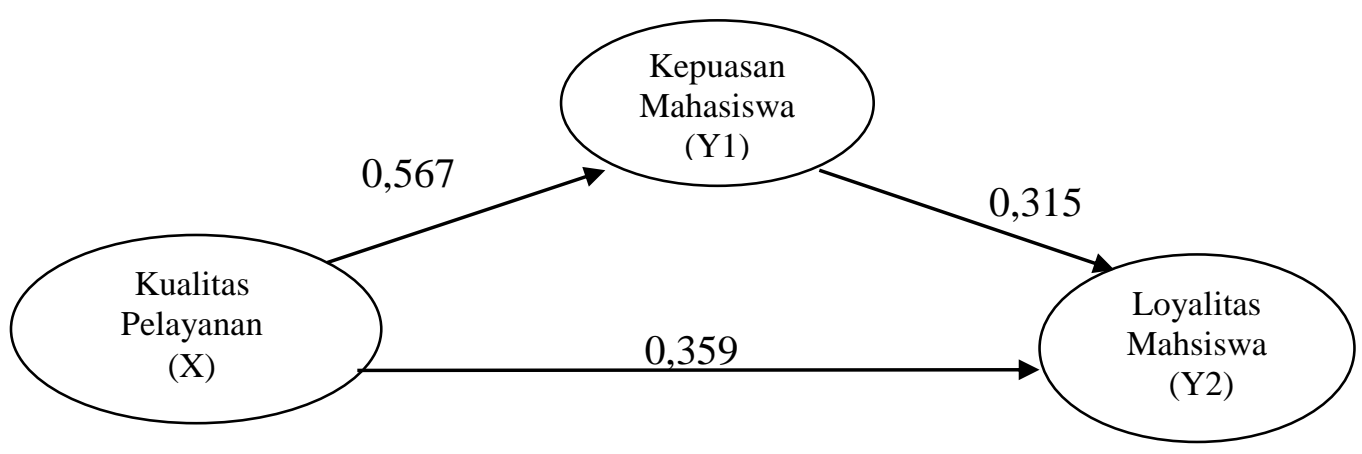

Gambar 3 Diagram Jalur Pengaruh Langsung

Sumber : Hasil pengolahan data 


\section{Pembahasan}

Berdasarkan hasil pengujian hipotesis secara statistik pada Tabel 19 dan Gambar 2 maka dapat disimpulkan sebagai berikut:

Hipotesis 1, yang menyatakan bahwa terdapat pengaruh positif dan signifikan antara kualitas pelayanan (X) dan kepuasan mahasiswa (Y1) adalah diterima dengan koefisien sebesar 0,567 dan p value sebesar 0,000. Artinya, bahwa kualitas Pelayanan berpengaruh positif dan signifikan terhadap kepuasan. Hasil ini sejalan dengan penelitian (Supriyanto et al., 2014) dan (Agung et al., 2011).

Hipotesis 2, yang menyatakan bahwa terdapat pengaruh positif dan signifikan antara kualitas pelayanan (X) dan loyalitas mahasiswa (Y2) adalah diterima dengan koefisien sebesar 0,359 dan $\mathrm{p}$ value sebesar 0,012. Artinya, bahwa Kualitas Pelayanan berpengaruh positif dan signifikan terhadap Loyalitas. Hasil ini sejalan dengan penelitian yang dilakukan oleh (Supriyanto et al., 2014) dan (Agung et al., 2011).

Hipotesis 3, yang menyatakan bahwa terdapat pengaruh positif dan signifikan antara kepuasan mahasiswa (Y1) dan loyalitas mahasiswa (Y2) adalah diterima dengan koefisien sebesar 0,315 dan $\mathrm{p}$ value sebesar 0,012. Artinya, bahwa Kepuasan berpengaruh positif dan signifikan terhadap Loyalitas. Hasil ini sejalan dengan penelitian yang dilakukan oleh (Supriyanto et al., 2014) dan (Agung et al., 2011).

\section{Implikasi Manajerial}

Temuan penelitian ini adalah kualitas pelayanan berpengaruh positif dan signifikan terhadap kepuasan dan loyalitas mahasiswa IOB di Timor-Leste. Oleh 
karena itu, maka implikasi manajerial dalam pengelolaan institusi adalah sebagai berikut :

a. Kualitas pelayanan menunjukkan pengaruh yang positif dan signifikan terhadap kepuasan dan loyalitas mahasiswa. Hal ini berarti bahwa selama ini kualitas pelayanan yang diterima oleh mayoritas mahasiswa IOB telah sesuai dengan harapan. Namun dari hasil penelitian ini pula menunjukkan bahwa ada mahasiswa yang belum puas terhadap kualitas pelayanan yang diberikan oleh IOB. Dengan demikian, pihak IOB dapat memperbaiki kualitas pelayanan yang sedang diterapkan sehingga semakin baik kualitas pelayanan yang diterima oleh mahasiswa IOB, maka tingkat kepuasan maupun loyalitasnya akan semakin tinggi.

b. Kepuasan menunjukkan pengaruh yang positif dan signifikan terhadap loyalitas mahasiswa. Hal ini menunjukkan bahwa semakin tinggi tingkat kepuasan yang dirasakan oleh mahasiswa, maka tingkat loyalitasnya pun akan semakin tinggi.

c. Pihak IOB dapat meningkatkan kepuasan dan loyalitas mahasiswa IOB dengan mengevaluasi kinerja serta kualitas pelayanan, dan memperbaiki strateginya kearah yang lebih baik, dengan memakai indikator-indikator dalam penelitian ini sebagai acuanya.

d. Berdasarkan penilaian responden terhadap indikator-indikator yang dipakai dalam penelitian ini, masih menunjukkan nilai ketidakpuasan terhadap kualitas pelayanan yang diberikan oleh IOB. Oleh karena itu diperlukannya perbaikan kualitas pelayanan di IOB, dengan mengacu pada indikator dalam penelitian ini 
yang mendapatkan respon yang kurang memuaskan, sehinga dapat meningkatkan kepuasan dan loyalitas mahasiswa IOB.

\section{Keterbatasan Penelitian}

Penelitian ini memiliki beberapa keterbatasan antara lain sebagai berikut :

a. Objek penelitian yang hanya ditujukan pada satu objek saja, yakni Institute of Business(IOB) di Tiomr-Leste, sehinga responden penelitian pun terbatas pada mahasiswa IOB Timor-Leste.

b. Hasil penelitian ini tidak dapat digeneralisasi untuk kasus diluar objek penelitian, karena setiap objek memiliki karakteristik yang berbeda. Penelitian mendatang diharapkan dapat memperluas ruang lingkup objeknya, tidak terbatas hanya pada mahasiswa yang masih aktif, namun dapat diperluas dengan mendapatkan informasi dari para alumni sebagai responden.

c. Penelitian ini hanya meneliti pengaruh kualitas pelayanan terhadap kepuasan dan loyalitas mahasiswa IOB di Timor-Leste. Penelitian selanjutnya diharapkan dapat mengkaji konstruk lain seperti kualitas pembelajaran yang mempengaruhi kepuasan dan loyalitas mahasiswa pada industria jasa pendidikan.

\section{SIMPULAN DAN SARAN}

\section{Simpulan}

Berdasarkan judul penelitian, pokok permasalahan, tujuan penelitian, rumusan hipótesis dan pembahasan hasil penelitian yang telah dibahas di bab-bab 
sebelumnya, maka dapat dikemukakan kesimpulan yang diambil adalah sebagai berikut :

a. Kualitas pelayanan berpengaruh positif dan signifikan terhadap kepuasan mahasiswa. Hal ini berarti bahwa dengan kualitas pelayanan yang semakin baik yang dapat diberikan oleh IOB, maka akan meningkatkan kepuasan mahasiswa, begitu juga sebaliknya.

b. Kualitas pelayanan berpengaruh positif dan signifikan terhadap loyalitas mahasiswa. Hal ini berarti bahwa dengan kualitas pelayanan yang semakin baik yang dapat diberikan oleh IOB, maka akan meningkatkan loyalitas daripada mahasiswa terhadap IOB.

c. Kepuasan mahasiswa berpengaruh positif dan signifikan terhadap loyalitas mahasiswa. Hal ini berarti bahwa semakin tinggi kepuasan mahasiswa, maka dengan sendirinya akan meningkatkan loyalitas daripada mahasiswa itu sendiri terhadap IOB.

\section{Saran}

Berdasarkan Hasil penelitian dan pembahasan, adapun saran yang dapat saya berikan untuk perbaikan kualitas pelayanan daripada pihak IOB di masa yang akan datang adalah sebagai berikut :

a. Berdasarkan hasil analisis yang dilakukan untuk mengetahui pengaruh kualitas pelayanan terhadap kepuasan dan loyalitas mahasiswa yang menghasilkan pengaruh positif dan signifikan, maka manajemen IOB sebaiknya melakukan perbaikan secara berkelanjutan untuk dapat meningkatkan kepuasan dan loyalitas dari para mahasiswanya sendiri. 
Manajemen IOB perlu memperhatikan perbaikan dari sisi pelayanan kepada mahasiswa, baik itu di pihak administrasi (pelayanan langsung terhadap mahasiswa), ataupun dari sisi tenaga pengajar. Untuk tenaga administrasi, hendaknya pihak manajemen IOB memberikan pelatihan (training) mengenai pelayanan kepada mahasiswa, dan juga pemberian kesempatan untuk meningkatkan jenjang pendidikan tenaga administrasi, dikarenakan dari input yang diberikan oleh mahasiswa, masih terdapat input yang kurang memuaskan terhadap pelayanan dari pihak administrasi IOB. Begitu pula untuk tenaga pengajar, hendaknya manajemen IOB melakukan penilaian kepada para tenaga pengajarnya secara rutin setiap semester, dengan tujuan agar bisa mendapatkan input dari para mahasiswa mengenai kualitas pelayanan dari para tenaga pengajar IOB. Hendaknya penilaian tersebut, dilakukan pula untuk pihak tenaga administrasi IOB.

b. Hasil penelitian ini dapat membantu manajemen IOB untuk memperbaiki diri, terutama pada bagian kualitas pelayanan pada bagian administrasi, yang dari hasil responden dari para mahasiswa, menunjukkan hasil yang kurang memuaskan, atau dengan kata lain, masih ada mahasiswa yang belum puas dengan kualitas pelayanan yang diberikan oleh IOB.

c. Hasil penelitian ini dapat memberikan kontribusi kepada pihak manajemen IOB untuk bagaimana mengambil keputusan yang strategis terhadap perbaikan kualitas pelayanan di IOB, sehinga dengan perbaikan terhadap kualitas pelayanan, maka dengan sendirinya akan meningkatkan kepuasan dan mencapai tujuan loyalitas daripara para mahasiswa terhadap IOB, sehinga 
dapat menekan keluhan dari para mahasiswa, dan juga meningkatkan imagepositif dari IOB di masyarakat.

d. Hasil penelitian ini dapat memberikan informasi yang berguna bagi manajemen IOB, terumata dalam hal peningkatan mutu pelayanan di IOB, sehingga tercapai kepuasan serta para mahasiswa, sehinga dapat memenangkan persaingan jasa pendidikan tinggi di Timor-Leste.

\section{REFERENSI}

Aaker, David. 1991. 'Managing Brand Equity: Capitalising on The Value of Brand Name. New -York: The Free Press.

Agustiono, Budi, dan Sumarno, 2006, "Analisis Pengaruh Kualitas Pelayanan Jasa terhadap Kepuasan dan Loyalitas Pasien Rawat Inap di Rumah Sakit St. Elisabeth Semarang”, EKSPLANASI, Vol. 1, no. 1, April 2006: 1 18.

Augusty Ferdinand, 2002, Structural Equation Modeling dalam Penelitian Manajemen, Semarang : Penerbit BP UNDIP.

Arikunto, Suharsimi, 1998, "Manajemen Penelitian", Cetakan Keempat, PT.Rineka Cipta, Jakarta.

Arbuckle, J. L., and Wothke, W., 1999, “Amos 4.0 User's Guide: SPSS”, Smallwaters Corporation.

Aritonang., Lerbin, 2007. Riset Pemasaran Teori dan Praktik. Bogor: Ghalia Indonesia.

Athanasia Astuti, Roy Mangungsong, Dwi Purnaningrum. 2014, Pengaruh kualitas pelayanan akademik terhadap kepuasan mahasiswa di Jurusan Terapi Wicara Poltekkes Kemenkes Surabaya, Jurnal Terpadu Ilmu Kesehatan, Vol. 3, No. 2: $106-214$.

Barata, Atep Adya, 2006, "Dasar-Dasar Pelayanan Prima”, Cetakan Ketiga, November 2006, Gramedia, Jakarta.

Bergin, Sarah, 1997, "Communication is the Key to Customer Success", Transportation and Distribution, March: $82-84$. 
Berry,L., Zeithaml,V., Parasuraman,A. 1998. The Service-Quality Puzzle. Business Horizons.

Chen, Yungkun, Chia-you Chen, Tsufiang Hsieh. 2007. Correlation of Service Quality, Customer Satisfaction, Customer Loyalty and Life Style at Hot Springs Hotels.

Cronbach Lee J. 1990, Essentials of Psychological testing, New York: HarperCollins Publisher, Inc.

Engel F James, Roger D. Blacwell and Paul W. Miniard, 1995, Perilaku Konsumer : Alih bahasa Budijanto, Binarupa Aksara, Jakarta

Ferdinand, A. 2002, Structural Equation Modeling Dalam Penelitian Manajemen, Semarang, Fakultas Ekonomi Universitas Diponegoro.

Hair, J.F., Anderson, R. E., Tatham, R. L., and Black, W. C., 1995, “Multivariate Data Analysis, Fourth Edition, New Jersey: Prentice Hall.

I Nyoman Rinala, I Made Yudana, dan I Nyoman Natajaya. 2013, Pengaruh kualitas pelayanan akademik terhadap kepuasan dan loyalitas mahasiswa pada sekolah tinggi pariwisata Nusa Dua Bali, e-Jurnal Program Pascasarjana Universitas Pendidikan ganesha, Vol. 4

Kotler Philip, 1997, Manajemen Pemasaran, Prenhallindo, Jakarta.

Kotler, Philip, 2002,Manajemen Pemasaran Jilid 1, Prenhallindo, Jakarta.

Kotler, Philip dan Keller, Kevin Lane. 2009. Manajemen Pemasaran. Jakarta: Erlangga

Line Lervik Olsen, Michael D. Johnson, 2003, "Service Quality: Satisfaction, and Loyalty: from transaction - specific to cumulative evaluation", Journal of Service Research, Vol. 5, no. 3.

Lupiyoadi, R. L dan Hamdan, A .2009. Manajemen Pemasaran jasa. Salemba Empat. Jakarta.

Lupiyoadi, R. L dan Hamdan, A .2008. Manajemen Pemasaran jasa. Salemba Empat. Jakarta.

Lupiyoadi, R. 2001. Manajemen Pemasaran : Teori dan Praktik. Jakarta : Salemba Empat

Moureen Margaretha, 2004, "Studi Mengenai Loyalitas Pelanggan pada Divisi Asuransi Kumpulan AJB Bumiputera 1912 (Studi Kasus di Jawa Tengah)", Jurnal Sains Pemasaran Indonesia, Vol. III, no. 3, Desember 2004: $289-308$. 
Muafi dan Yuni Siswanti, 2007, “Anteseden Ekuitas Merek Perguruan Tinggi:

SEM dengan Pendekatan Two Step", Manajemen Usahawan Indonesia, no. 03, TH XXXVI, Maret, 2007: 27 - 34.

Parasuraman, A., Valerie Zeithaml, and L.Berry, 1988, "Servqual: Multiple Item

Scale for Measuring Consumer Perceptions of Service Quality", Journal of

Retailing, Vol. 64: $12-36$.

Santoso, S. 2011. Stuctural Equation Modeling (SEM).Konsep dan Aplikasi dengan AMOS 18. Jakarta: PT Alex Media Komputindo.

Storey, Chris and Christoper J. Easingwood, 1998; "The Augmented Service Offering a Conceptualization and Study of its Impact on New Service Success", Journal of Product Innovation Management, Vol. 15.

Sugiyono. 2009. Metode Penelitian Bisnis, Cetakan Keenam. CV Alfabeta. Bandung.

Supriyanto, Nur Estri, Agustini Tripena. 2014, Analisis pengaruh kualitas pelayanan jasa pendidikan terhadap kepuasan dan loyalitas mahasiswa menggunakan Structural Equation Modelling, JMP, Vol. 6, No. 1: 23 - 32.

Supranto, J. 2000. Pengukuran Tingkat Kepuasan Pelanggan untuk meningkatkan Pangsa Pasar, Penerbit Rineka Cipta, Jakarta.

Sutino dan Sumarno, 2005, "Pengaruh Kualitas Produk (Jasa) dan Kualitas Pelayanan terhadap Kepuasan dan Loyalitas Pelanggan di PT.POS Indonesia Semarang 50000", Majalah Ilmiah Kopertis Wilayah VI, Vol. XV no. 23, April/ Mei 2005: 9-20.

Tjiptono, Fandy 1997,’Strategi Pemasaran”, Edisi II, Andi, Yogyakarta.

2011. Service, Quality \& Satisfaction, Edisi 3. Andi Offset. Yogyakarta.

Tjiptono, Fandy dan Gregorius, Chandra. 2007. Service, Quality and Satisfaction edisi kedua. Yogyakarta : CV Andi. 